\title{
Estonians in the Crimea
}

\author{
JÜRI VIIKBERG, Ph.D., Senior Researcher ${ }^{1}$ \\ OTT KURS, Ph.D., Professor ${ }^{2}$ \\ ${ }^{1}$ Institute of Estonian Language, Tallinn, Estonia \\ ${ }^{2}$ Chair of Human Geography, Tartu University, Estonia
}

\begin{abstract}
The article gives an overview of Estonian peasants settling in the Crimea in the mid$19^{\text {th }}$ century. Having for several centuries been under the control of the Golden Horde and the Crimean Khanate, the Crimean Peninsula was annexed by Russia in 1783. The imperial colonization policy that succeeded the deportation of the Crimean Tatars to Turkey encouraged the peasants of the Estonian and Livonian gubernias to emigrate to the Crimea. The driving forces behind the emigration were not only economic but also religious. For the members of a sect led by the Prophet Maltsvet the Crimea had become the Promised Land.
\end{abstract}

The first Estonian settlements in the Crimea were founded in 1861-1864. Their names Zamruk, Kara-Kiyat, Konchi-Shavva, etc., indicate that the Estonians settled in the deserted villages of Crimean Tatars. After a long journey and in an unfamiliar setting, it was difficult to adapt to and start a new life, but by the 1880s, the settlers had already established themselves. Sharing the community of interests, they built schools and churches together. When the Estonian writer Eduard Vilde came to see the Crimean Estonians in 1904, he could only give high praise for their efforts.

By the beginning of World War I, the Estonians in the Crimea had achieved a living standard which was the highest when compared to other Estonians in Russia. In 1921, the number of Estonians in the Crimea was 2,367, whereas in 1995 there were only about 500 Estonians living mainly at Beregovoe (Zamruk), Krasnodarka (KonchiShovva) and Novo-Estonia. Since the 1990s, Estonian cultural activities have again become possible in the Crimea. In Simferopol and Krasnodarka Estonian societies have been established and any support from native Estonia would be welcome. From autumn 2002, a native language teacher from Estonia started to work at the Krasnodarka secondary school.

Keywords: Crimea, Crimean Estonians, Crimean Tatars, immigration, integration 
The investigations of Estonian diasporas began in the 1980s as linguistic studies of the Siberian-Estonians (Viikberg and Vaba 1984; Viikberg 1989; 1992, etc.). In the 1990 s, they continued on to the geography (Kulu 1992; 1997) and folklore (Korb 1995, Korb and Tamm 1996, etc.) of the Siberian-Estonians and to the sociolinguistics of the Swedish-Estonians (Klaas and Laagus 1998). In September 1997, a special seminar on the Estonian language spoken by Estonians in different parts of the world was held at Tartu University. The reports of the seminar were published as a collection (Lindström 1998). A survey of Estonian sociolinguistics, including the Estonian spoken outside Estonia, was published in 1999 in a special issue of the International Journal of the Sociology of Language (Hennoste 1999). In August 2000, the Ministry of Education organized an international conference on the Estonian language around the world (Valge 2002) and in 2001, together with the Crimean Ethnographical Museum, it organized a conference on the Estonian diaspora in the Crimea. The materials of the last conference were published in the Krimmi kogumik (Crimean Papers, Viikberg 2002). Currently at Tartu University (under the leadership of the Chair of the Archives), an interdisciplinary research project on the eastern Estonian diaspora for the years $2003-08$ is being assembled. Below is a short description of the 140-year-old Estonian diaspora in the Crimea.

\section{The Crimea as a part of the Black Sea Region}

The Black Sea - 420,300 $\mathrm{km}^{2}$ with the Sea of Azov - is a little larger than the Baltic Sea $\left(386,000 \mathrm{~km}^{2}\right)$. In comparison with the Baltic Sea, the Black Sea does not have as many bays, gulfs, coves, inlets, islands or peninsulas. The largest peninsula of the Black Sea - the Crimea - is situated in the extreme south of Eastern Europe. The peninsula is a natural and historical and geographical borderland between the Eastern Mediterranean and continental Eurasia. It is almost surrounded by water because the Perekop Isthmus that joins it to the mainland is only eight kilometers wide.

Due to the Crimea's maritime location and favorable climate, its coasts were settled in ancient times by Greeks, Armenians and Jews, and at the beginning of the Middle Ages, its steppes were populated by Turkic Cumans (Pecheneges and Polovets). Since the times of the Golden Horde $\left(13^{\text {th }}-15^{\text {th }}\right.$ centuries), the Turkic people here have been Crimean Tatars, Karaims and Krimchaks. During the $15^{\text {th }}-18^{\text {th }}$ centuries, the Peninsula was a core of the Crimean Khanate lying on the northern and northeastern coastal areas of the Black Sea. The Khanate had a mainly Islamic population, but there were also minority groups of the Jewish and Christian faiths.

In 1783, the Crimean Khanate was conquered by Russia. To Russian leaders, the Crimea, with its steppes, mountains and coasts, and especially with its subtropical southern coast, became a sort of Garden of Eden, a paradise on earth (Schönle 2001). Then a cruel period of violence toward the indigenous population began. Russians and Ukrainians, as well as Germans, Greeks, Bulgarians, Armenians, Jews, Estonians, 
Figure 1. The Crimea and the Black Sea region

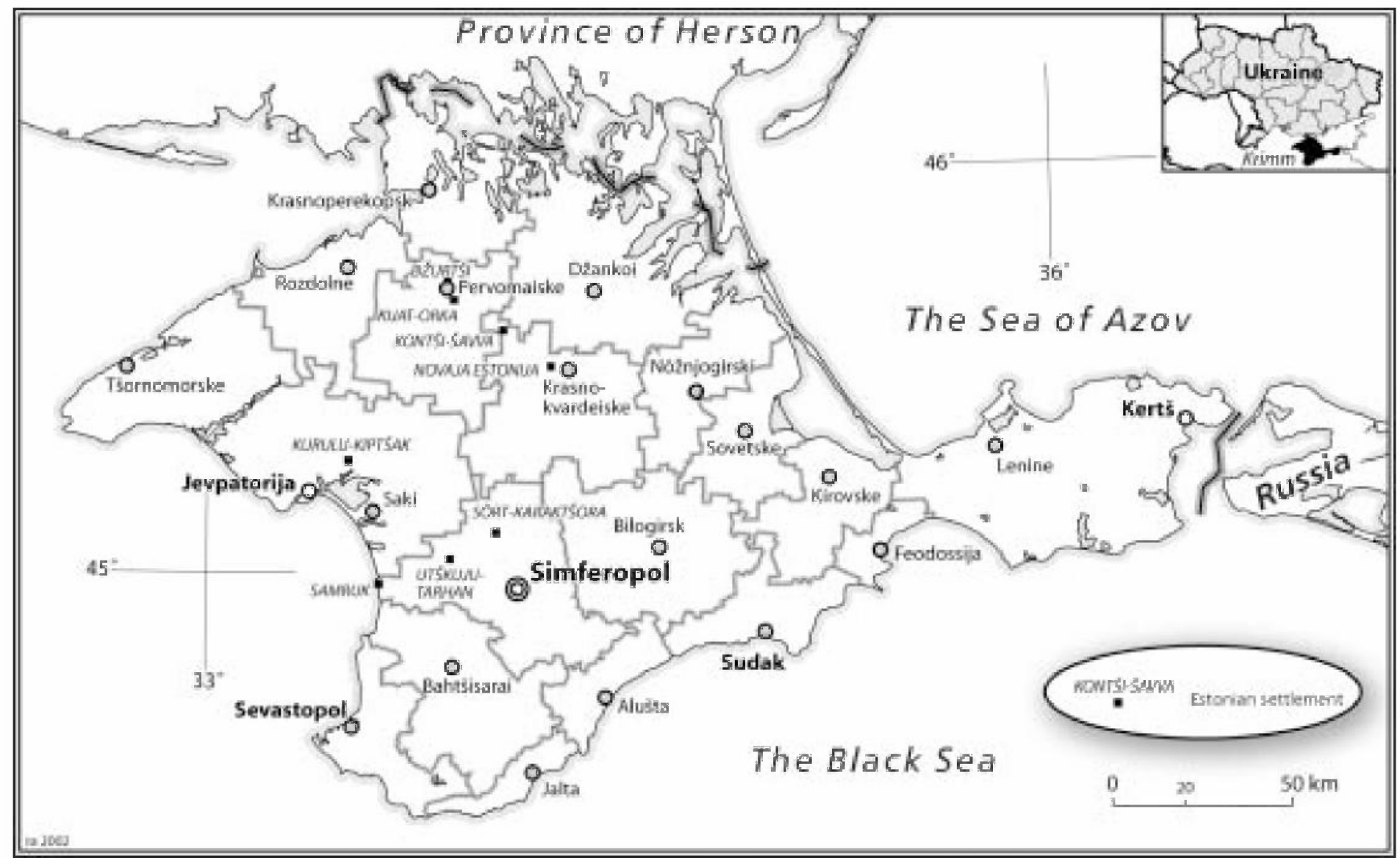


Poles, Lithuanians and others were lured there to replace the exiled and deported Crimean Tatars (Kurs 2002).

\section{The migration of Estonians to the Crimea}

In the $19^{\text {th }}$ century, the primeval Estonian settlements areas were divided between two Lutheran and two Orthodox gubernias. Most of the Estonians - 750,000 inhabitants in 1858 and 956,000 in 1897 - lived in the Lutheran Estonian and Livonian gubernias. The Estonian gubernia (Eestimaa kubermang) had an entirely Estonian population, but in the Livonian gubernia (Livimaa kubermang) Estonians settled only in the northern part. The $19^{\text {th }}$ century was characterized by a rapidly increasing population. The main positive factors impacting the birth rates were: (a) the abolition of serfdom (in 1816 in the Livonian gubernia and in 1819 in the Estonian gubernia); (b) expanding tillage; (c) increasing potato growing; (d) decreasing of mortality from infectious diseases (smallpox, etc.) by vaccination. So, in the second half of the $19^{\text {th }}$ century new phenomena arose such as the migration of rural population into towns and emigration into Russia. The passport law in 1863 and the development of the railway system helped make this possible.

The migration of Estonian peasants to the areas of the Russian empire began in the mid $-19^{\text {th }}$ century and it was influenced by several external and internal factors.

The external factors were the Russian conquests in the Black Sea region and in the east. During one of the numerous Russian-Turkish wars (1676-1878), the Crimea was finally annexed by the Russians in the course of the Crimean War (1853-1856). To gain hold of the new territory, the Crimea was settled with colonists from other parts of Russia, supported by the state and made easier by the forced migration of the local Crimean Tatar population to Turkey. While Estonia and Livonia had been, since 1721, part of the Russian empire, opportunities for emigration also opened for the Estonian peasants.

Internal factors were the economic situation of the Estonian peasants (the replacement of corvée by monetary rent in 1856), the example set by those who emigrated to Samara in the late $1850 \mathrm{~s}$ as well as religious movements. One of the characteristic features of the Crimean migration is that the majority of the settlers were members of a sectarian movement led by the Prophet Maltsvet (a movement opposed to the United Brethren movement). The Maltsvet supporters came mostly from the Paide Parish in Järvamaa County and from the Parish of Kuusalu in Harjumaa County (both in Northern Estonia). The Prophet Maltsvet was to lead his people from exile in Babylon to Canaan - to the Crimea. So the Crimea was the Promised Land.

The first Estonian settlers from Järvamaa arrived in the Crimea in August and September 1861 (Viikberg 2002). The first group of five families under the leadership of 
Aabram Nord reached Aktachi-Kiyat - one of the deserted Crimean Tatar villages on the Salgir River at the beginning of August. Later, this village was renamed after Aabram Nord as Abramovskoe. The second group (with Hendrik Selbak and Gustav Malts as leaders) of 23 families (about 120 persons) arrived in Zamruk on the western Crimean coast in November. From there ten families later migrated to Aktachi-Kiyat.

At the beginning of August 1862, about 580 Estonian peasants under the leadership of Gustav Määrmann arrived in Simferopol. A smaller group led by Ants Valkmann came there at the end of August and settled at Kara-Kiyat. These Estonian settlers were divided among two landowners, Galaiev (118 families) and Belovodova (113 families).

The Estonian press carried articles about the Crimea, the migration to the Crimean Peninsula and the Estonian settlers' life in the Crimea. The articles were critical of the migration and the hardships of the first years were highlighted. The long journey from Estonia to the Crimea and starting a new life were naturally difficult. But in the course of time, the hard-working Estonians coped with everything and Estonian settlements were founded. Later, such Estonian settlements as Dzhurchi (1863), Konchi-Shavva (1863), Syrt-Karakchora (1864) and Uchkuyu Tarkhan (1879) were founded (Viikberg 2002).

According to the census of the population, the number of Estonians in the Taurian gubernia in 1897 was 2,210 ( $0.4 \%$ of the total population), and in the Crimea - in the main part of this gubernia - 2,176 persons. The Crimean Estonians formed $1.9 \%$ of the total population of Russian Estonians (113,813 inhabitants). In 1926, the census counted 2,084 Estonians in the Crimean ASSR, of whom 1,872 spoke Estonian (89\%). A total of 1,570 Estonians lived in villages (with 97\% proficient in Estonian), while 514 lived in cities (with $68 \%$ speaking Estonian as a mother tongue). The other settlers of the Lutheran faith in the Crimea were Germans $(40,160)$ and Latvians $(185$ inhabitants). When the writer Eduard Vilde went to see the Estonians in the Crimea in 1904, he could but praise his industrious kinsmen.

The number of Estonians in the Crimea was always smaller than that of other immigrants. The populations of different ethnic groups were repeatedly "corrected" (deported) by the Russian and Soviet authorities. Immediately after the annexation of the Crimea in 1783, 300,000 Crimean Tatars were deported. On February 3, 1798 a Manifesto for the colonization of the Crimea by foreign immigrants was adopted. Tens of thousands of Germans, Bulgarians, Anatolian Greeks and other immigrants took advantage of this possibility.

In unfamiliar conditions the Estonians held together and developed cooperation. In the beginning they lived in abandoned clay huts until new dwellings were built. When the first economic difficulties had been overcome, building a schoolhouse and a church in the village was considered most important. Schoolteachers were invited from Estonia. Later, Estonian settlers were in better condition, because they could choose land 
for themselves. The mediators were German, Jewish and Russian merchants. Thus the Estonian settlements of Kara-Kiyat (at present: Upornoe), Uchkuyu-Tarkhan (Kolodeznoe), Konchi-Shavva (Krasnodarka), Boz-Goz, Yapunca, Dzhurchi (Pervomaiskoe) and Chaga-Kushi (Okhotnikovo) came into being. Every male in a household got 13-16 hectares of land and each family 100 rubles of irrevocable aid. If crops failed three years running, seed grain was provided free-of-charge by the state. The settlers were exempt from taxes for 8-10 years and from military service for two years.

The everyday contacts of Estonians with the indigenous Crimean Tatars were minimal, because the Estonians were settled in places from where the Crimean Tatars had already been deported. Later some Crimean Tatars from neighboring villages worked on the more wealthy Estonian farms. The common colloquial language the Tatars used with the Estonians and other immigrants was Russian. The level of education of the Tatars in these parts of the Crimea was low, and so they did not differentiate between Estonians and other immigrant groups.

\section{About the Estonian village of Zamruk (Beregovoe)}

The life of settlers in 1861-62 was not easy. Poor living conditions, disease and a lack of Russian language skills made it difficult to adapt to the new environment. A large number of Estonians returned to their homeland or moved from the Crimea to the North Caucasus. There is a new publication on the Estonian settlement of Zamruk based on archival documents (Karkach 2002). According to this paper, in 1876, 24 Estonian households were situated in Zamruk. By the end of the $19^{\text {th }}$ century, Estonians had received 1,310 hectares of the Crimean Tatar community land in Zamruk. They enlarged their properties by gradually acquiring one piece of land after another. In 1880, there were 211 villagers in Zamruk or Beregovoe (as the village then officially was renamed), and Estonian households had a large number of domestic animals, tools and implements. In 1912, the Beregovoe Estonians abandoned the community land system and their farms were marked in the village plan. In 1913, the Estonian lands in the former Crimean Tatar lands of Zamruk were also marked off. In 1915, there were 43 households in Beregovoe with 153 inhabitants. The farming lands made up 15,380 hectares. In 1926, 210 Estonians lived in Beregovoe. They also had an Estonian school there.

The Crimean Estonians used their own household products for food. They grew wheat, barley and oats and their staple food consisted of cereals and flour products. The main products that were imported were salt, salted fish, fruits and vegetables (turnips, carrots, cabbage, onions and pumpkins, later also marrow squash and aubergines). By the end of the $19^{\text {th }}$ century, when the economic and social conditions of the Estonians peasants had improved, the number of domestic animals and the consumption of meat increased. In the $20^{\text {th }}$ century, new dishes appeared in the peasants' fare, dishes already familiar to town-dwellers (meatloaf, meatball soup) and there was a variety of 
food. Potatoes did not spread to the Crimea until the early 1960s. The late use of potatoes can be explained with the aridity of the steppes and the lack of any irrigation (Prokofieva 2002).

\section{Potrayals of the Crimean Estonian by writers and journalists}

The Estonian press carried articles about the Crimea and the Estonian settlers' life there. The articles were critical of the migration and the hardships of the first years were highlighted. In September and October 1904, the Estonian novelist Eduard Vilde (1865-1933) took a long journey to visit the Estonian settlements in the Crimea and the Caucasus. In Simferopol and the Estonian settlements of Tarkhan, Zamruk, KonchiShavva, Boz-Goz, Syrt-Karakchora and Dzhurchi, which Vilde visited, he listened to the recollections of the elderly emigrants and got hold of a very valuable manuscript by one of the leaders, Gustav (also: Kustav) Malts, called the History of the Maltsvet faith and emigration to the Crimea. This manuscript was the main source for Vilde's novel Prophet Maltsvet, the final version of which came out in book form in 1908 (Süvalep 2002). In late 1904 and early 1905, Vilde also published a lengthy travelogue entitled On a visit to the Crimean and Caucasian Estonians (Vilde 1956). The life of the Crimean Estonians until the beginning of the 1920s has been described by the Estonian Ottomar Laamann (1900-1988), who later moved to Canada (Laamann 1981).

\section{Estonians in the Crimea during the Soviet period}

In 1921, the Crimean Autonomous Soviet Socialist Republic (Crimean ASSR) was formed. The Crimean ASSR was a multiethnic territorial society including 2,367 Estonian inhabitants $(0.3 \%)$ in 1921 . They were mostly a rural people. A total of 1,570 Estonians (with 97\% proficient in the Estonian language) lived in villages and 524 in cities (276 in Simferopol, 218 in other cities). More than a half of the Estonians, 878 persons, lived in 31 villages of the Chankoy district (115 in Boz-Goz, 213 in Dzhurchi, 215 in Konchi-Shavva, 53 in Novaia Estonia and 126 in Syrt-Karakchora), thus comprising the seventh largest ethnic group. The Simferopol district had 518 Estonian inhabitants (210 in Zamruk and 133 in Uchkuyu-Tarkhan). In 1930 two Estonian villages in the Simferopol district and one in the Chankoy district were subordinated to the village councils.

As to the repressions, in 1926 a new means of political persecution was introduced the denial of the right to vote. According to the Soviet law, the right to elect and to be elected belonged to the working people, excluding merchants, small proprieters and persons who used employed labor. So we can claim that the New Economic Policy (NEP) (1921-1928) was a trap for those who began to make use of the opportunities it offered as they then turned out to be a "non-working-element". There were many people in Beregovoe who were repressed for this reason. Some scholars have not even 
regarded the denial of the right to vote as a repression. As a matter of fact, this was the beginning of the limitations imposed on the economic and social rights of individuals. People who lacked the right to vote did not receive food coupons, they could be evicted from communal apartments, they could not continue their studies, be employed in civil service, etc. The people with no right to vote usually suffered from repressions which were more severe.

After the adoption of the USSR Constitution (1936) the right to vote was returned, but new waves of repressions were ahead - especially in the tragic years of 1937 and 1938. The "enemies of the people" had been repressed earlier, but this turned out to be the climax. After 1939 the persecution diminished, although it persisted, to a lesser degree, in the subsequent years.

So the number of Estonians in the Crimea decreased: 1,900 Estonians $(0.2 \%$ of the total population) in 1939, 1,291 in 1970, 1,048 in 1979 and 985 in 1989. About onethird still speak Estonian.

\section{Estonian diaspora in the Crimea today}

The most numerous non-Russian ethnic immigrant groups of the Crimea in June 1944 were the Greeks $(20,652$ inhabitants), Bulgarians $(12,652)$ and Armenians (at least $12,000)$. All these groups, as well as Germans $(61,184$ persons) already in 1941 , were deported to the Urals and Siberia (Raiser and Laptew 2000: 3). In 1944, also all the Crimean Tatars and part of the Karaites were deported from the Crimea.

After a long and hard but peaceful struggle for the right to return to their homeland, the Crimean Tatars have been arriving since the late $1980 \mathrm{~s}$. Of the deportees a little more than half - about 300,000 - have returned. Parts of other groups have also returned: Germans, Greeks, Bulgarians, Armenians and other smaller ethnic groups. Now, after the return of more than half of the Crimean Tatars, the composition of the population is again diversified, and the Crimean Tatars are the third largest ethnic group after the Russians and Ukrainians, constituting $12 \%$ of the total population of the Crimean Autonomous Republic (Kurs 2002). Smaller ethnic groups now form about $3 \%$ of the total population.

Today, Estonians live in the villages of Vilino (with the ancient Crimean Tatarian name of Bürlük) and Beregovoe (Zamruq) (district of Bagçasaray), Krasnodarka (Qonçi-Savva, 50 families) and Novoestonia (district of Krasnogvardeiskoe, earlier Qurman-Kemelçi) and in the borough of Pervomaiskoe. ${ }^{1}$ The Crimean Estonian Society was organized on April 7, 1997 and registered on October 10, 1997. The leader of

\footnotetext{
${ }^{1}$ As the Crimean Tatar language now once again uses the Roman alphabet, we are doing the same with the Crimean Tatar placenames in this article.
} 
the Society is Mrs. Meri Nikolska, who was born in the Crimea, but completed classes 2-4 in postwar Estonia, in the vicinities of the towns of Antsla and Türi. She then returned to the Crimea and continued her studies in the local rural school of the collective farm Linda and in a technical college in Simferopol.

It is absolutely necessary to support the smaller cultural ethnic groups of the Crimea. Good initiatives in this field have been made by Germany, the Czech Republic and Poland. It is necessary for the Karaites and Lithuanians living in the Crimea to be supported by Lithuania, the Latvians by Latvia and the Estonians by Estonia. In the Crimea, the number of Estonians is close to the number of Karaites. In any case, with the help of the Ministry of Education of the Republic of Estonia, Estonian as a language began to be taught in the Secondary School of Alexandrovka in September 2002.

\section{References}

Hennoste, Tiit. 1999 (editor). Estonian Sociolinguistics. International Journal of the Sociology of Language 139. General editor Joshua A. Fishman. Berlin-New York: Mouton de Gruyter, 1999.

Karkach, Yelena. 2002. Poselenie estoncev v selo Zamruk v dokumentakh gosudarstvennogo arkhiva Kryma. With English Summary: About the history of Zamruk, an Estonian settlement in the Crimea based on documents in the Crimean State Archives. In: Krimmi kogumik [The Crimean Papers], compiled and edited by Jüri Viikberg. Tallinn: Eesti Teaduste Akadeemia Emakeele Selts, Eesti keelenõukogu, pp. 64-75.

Klaas, Birute, and Aino Laagus. 1998. Eesti keel Lõuna-Rootsis [The Estonian language in Sweden]. In: Väliseestlaste keelest [The Estonian language abroad]. Tartu Ülikooli eesti keele õppetooli toimetised 9, edited by Liina Lindström. Tartu, pp. 39-54.

Korb, Anu. 1996. Ei oska rääkimise moodi kõnelda [Southern Estonian texts]. In: Eesti asundused II [Estonian settlements II], compiled by Anu Korb, edited by Kadri Tamm. Tartu: Eesti Kirjandusmuuseum.

Korb, Anu. 1998. Seitse küla Siberis. [The seven villages in Siberia]. In: Eesti asundused III [Estonian settlements III], compiled by Anu Korb, edited by Kadri Tamm. Tartu: Eesti Kirjandusmuuseum.

Korb, Anu. 1999. Taaru-tagused ja stepiasukad [Living behind the River Tara and in the steppes]. In: Eesti asundused $I V$ [Estonian settlements IV], compiled by Anu Korb, edited by Kadri Tamm. Tartu: Eesti Kirjandusmuuseum.

Korb, Anu and Kadri Peebo. 1995. Siin Siberi maa peal kasvanud. [Grown up in Siberia] In: Eesti asundused I [Estonian settlements I], compiled by Anu Korb and Kadri Peebo. Tartu: Eesti Kirjandusmuuseum. 208 pp.

Kulu, Hill. 1992. Eestlased maailmas. Ülevaade arvukusest ja paiknemisest. With english summary: Estonians in the World. An Overview of Number and Localization 1850-1990. Tartu: Tartu Ülikool.

Kulu, Hill. 1997. Eestlaste tagasiränne 1940-1989. Lääne-Siberist pärit eestlaste näitel. With english summary: Estonian Return Migration 1940-1989. A Case of West-Siberian Estonians. Publicationes Instituti Geographici Universitatis Helsingiensis 9. Helsinki.

Kulu, Hill, Katrin Metsis and Tiit Tammaru (editors). 1997. Eestlane olla... Eesti keele ja kultuuri perspektivid [To be an Estonian. Prospects of the Estonian language and culture abroad]. Tartu: Tartu Ülikool. 
Kurs, Ott. 2002. Turgi rahvad Krimmis. With english summary: Turkic people in the Crimea. In: Krimmi kogumik [The Crimean Papers], compiled and edited by Jüri Viikberg. Tallinn: Eesti Teaduste Akadeemia Emakeele Selts, Eesti keelenõukogu, pp.110-31.

Laamann, Ottomar. 1981. Mälestused Krimmist [My memoirs of the Crimea]. Toronto: Estoprint. Lindström, Liina. 1998. Väliseestlaste keelest [The Estonian language abroad]. Tartu Ülikooli eesti keele õppetooli toimetised 9, edited by Liina Lindström. Tartu.

Omelchuk. Dmitrii. 2002. Repressii protiv estonskogo naseleniya Kryma (20-30-e gody XX veka). With english summary: On the repressions of the Crimean Estonians in the 1920s1930s. In: Krimmi kogumik [The Crimean Papers], compiled and edited by Jüri Viikberg. Tallinn: Eesti Teaduste Akadeemia Emakeele Selts, Eesti keelenõukogu, pp. 88-96.

Prokofieva, Yelena. 2002. Kultura i tradicii kukhni krymskikh estoncev (po vospominaniam starozhilov). With english summary: Food culture and eating habits of the Crimean Estonians. In: Krimmi kogumik [The Crimean Papers], compiled and edited by Jüri Viikberg. Tallinn: Eesti Teaduste Akadeemia Emakeele Selts, Eesti keelenõukogu, pp. 76-87.

Raag, Raimo. 1995. Virolaiset Viron ulkopuolella [Estonians outside Estonia]. In: Viro: Historia, kansa, kulttuuri [Estonia: History, people, culture], edited by Seppo Zetterberg. Helsinki: Suomalaisen Kirjallisuuden Seura, pp. 339-76; 384-5.

Raag, Raimo. 1999. Eestlane väljaspool Eestit. Ajalooline ülevaade [An Estonian outside Estonia. A historical overview]. Tartu: Tartu Ülikool.

Raiser, Wiktor and Jurii Laptew. 2000. Nemcy v Krymu. Deutsche auf der Krim. Simferopol: Tavrija-Pljus.

Schönle, Andreas. 2001. Garden of the Empire: Catherine's appropriation of the Crimea. Slavic Review 1:1-23.

Süvalep, Ele. 2002. Tõotatud maale. Hinnanguid eestlaste Krimmi asumisele Eduard Vilde reisikirjas ning romaanis "Prohvet Maltsvet". With english summary: To the Promised Land. Opinions on the Estonian migration into the Crimea in a travelogue and novel Prophet Maltsvet by Eduard Vilde. In: Krimmi kogumik [ The Crimean Papers], compiled and edited by Jüri Viikberg. Tallinn: Eesti Teaduste Akadeemia Emakeele Selts, Eesti keelenõukogu, pp. $49-63$.

Valge, Jüri. 2002. Eesti keel ja kultuur maailmas. 13.-15. August 2000, Tartu. Ettekanded. [The Estonian language and culture in the World. Papers of the seminar in Tartu, Estonia, August 13 to 15, 2000]. Edited by Jüri Valge. Eesti Vabariigi Haridusministeerium, Eesti Instituut. Tartu: Atlex.

Viikberg, Jüri. 1989. Suomalais-virolaisia kielisuhteita Siperiassa [About Estonian-Finnish language contacts in Siberia]. Virittäjä 1:79-88.

Viikberg, Jüri. 1992. Estonians in Siberia. Fenno-ugrica Suecana 11:79-90.

Viikberg, Jüri. 1999. Language shift among Siberian Estonians: pro and contra. In: Estonian Sociolinguistics, edited by Tiit Hennoste. International Journal of the Sociology of Language 139, general editor Joshua A. Fishman. Berlin-New York: Mouton de Gruyter, 1999, pp. 10524.

Viikberg, Jüri. 2002. Krimmi kogumik. [The Crimean Papers]. Compiled and edited by Jüri Viikberg. Tallinn: Eesti Teaduste Akadeemia Emakeele Selts. Eesti keelenõukogu. 240 pp.

Viikberg, Jüri. 2002. Eestlaste väljarändamine Krimmi. Summary: The migration of the Estonians into the Crimea. In: Krimmi kogumik [The Crimean Papers], compiled and edited by Jüri Viikberg. Tallinn: Eesti Teaduste Akadeemia Emakeele Selts, Eesti keelenõukogu, pp. 2148.

Viikberg, Jüri, and Lembit Vaba. 1984. Siberi põhjaeestlasi kõnetamas [Speaking with the Northern Estonians in Siberia]. Keel ja Kirjandus 3:145-56; 4:210-23.

Vilde, Eduard. 1956. Krimmi ja Kaukaasia eestlastel külaliseks [A visit to the Crimean and Caucasian Estonians]. In: Teosed. Reisikirjeldused. Tallinn: Eesti Riiklik Kirjastus, pp. 231387. 